DOI http://dx.doi.org/10.18551/rjoas.2016-03.05

\title{
CONTRIBUTION OF FUELWOOD MARKETING TO SUSTAINABLE LIVELIHOOD IN OYO STATE
}

\author{
Olugbire 0.0..$^{1 *}$, Aremu F.J. ${ }^{2}$, Opute O.H. ${ }^{1}$, Ojedokun C.A. ${ }^{1}$, \\ Ayomide A.A. ${ }^{\prime}$, Oguntoye T.O. ${ }^{1}$ \\ ${ }^{1}$ Forest Economics and Extension Services Department, Forestry Research Institute \\ of Nigeria, Ibadan, Nigeria \\ ${ }^{2}$ Department of Agricultural Economics, Obafemi Awolowo University, Osun state, Nigeria \\ *E-mail: olugbireolutoyin@gmail.com
}

\begin{abstract}
Fuel wood is an important source of income and domestic energy for both rural and urban households in Nigeria. The marketing of fuel wood in Ibadan, Oyo state, Nigeria was investigated with a view to assess the profitability and contribution of fuelwood marketing to sustainable livelihood in Oyo state. Data for the study were obtained from a total of 50 randomly selected respondents through interview schedules, structured questionnaires applications and personal observation. Descriptive statistical tools such as frequency, percentages and tables were used to analyze variables of interest such as age, gender, marital status, education, tribe, experience and type of institution. Profitability analysis was used to examine the profitability of the enterprise. The results revealed that majority $(86 \%)$ of the marketers were females, $44 \%$ had only primary education while $36 \%$ had 11 to 20 years of the business experience. The Profitability analysis revealed that an average marketer incurred an average of total variable cost of 31,731.82 naira per month but earned average revenue of 38,290.00 naira which indicated that an average marketer earns 6,558.18 naira as gross margin per month. This thus indicated that fuel wood marketing is profitable. Transportation, season and government policy are the major marketing constraints of fuel wood. It is therefore recommended that government should provide good transportation incentives such as good road networks that will reduce the transaction costs and make transportation easy for fuel wood marketers.
\end{abstract}

\section{KEY WORDS}

Fuel wood, profitability, marketing.

The functions performed by forests in human societies and its evolvement is enormous than any other resource. Wood which is a major forest product that can be used as timber, pulp and paper or fuel wood provides about 3.4 billion cubic meters of timber equivalent annually in all over the world (FAO, 2004). Fuel wood is a non-timber forest product (NTFP) used for industrial and domestic generation of energy especially in developing countries and felling of trees for fuel wood is now consider as the third most important economic activity of people in forest dependent areas followed by farming and animal rearing (FAO,1990). Several reasons make the use of fuel wood a location and situational specific source of energy and this may range from social, cultural, environment to economical reason (Horgan, 2001). Previously, wood were harvested in developing countries solely for immediate consumption and was mostly carried out by women and children who gathered the dry tree parts such as trunks, branches and shrubs for fuel wood but nowadays, sporadic rise in the commercialization of agricultural sector has brought about widespread harvesting of both dead and live branches and tree trunks by men, women and children (Awah, 1995). Fuel wood marketing like every other marketing enterprise involves the exchange between a buyer and a seller at a given price in such that the seller meets the total cost and the profit margin (Kalu et al, 2009; Browning, 1992; Cleaver, 1985).

Marketing is also considered as the collection of all business activities involves in the transferring of commodities from the point of production to the final consumers.

Marketing of fuel wood is simple, basically from producers to consumers in most cases except in few cases where urban fuel wood sellers come to buy in bulks. Large number of 
prepared- food vendors such as restaurants, vendors of barbecue (Suya) and party event outfit that served at celebrations and bakeries are regular customers of fuel wood sellers but institutions such as hospital, schools and prisons and also industries such as blacksmiths are among the highest fuel wood consumers (Larinde and Olasupo, 2011). The destruction of trees and natural ground covers were reported to alter the water retention capacity of soil which therefore reduce the productive capacity of soil. This then led to poor farm yield and made some farmers to resort to alternative activities like fuel wood marketing (Orosanye, 2003) but the farmers had little or no fore-knowledge on the profitability of this new venture and possible constraints they are likely to encounter along the way. This paper seeks firstly: to examine the socio-economic characteristics of fuel wood marketers, secondly, to examine the profitability of fuel wood market and finally, to examine the challenges faced by the fuel wood marketers along the business line. This research add to existing knowledge on fuel wood business and provide information for policy makers and private investors about prospect for fuel wood business in Oyo state, Nigeria.

Use of fuelwood and livelihood. About two billion people use fuelwood and charcoal as their main source of energy for cooking and heating their homes in the world (CIFOR, 2009). It is estimated that over $70 \%$ of the Nigerian population lives in the rural areas and use fuel wood for cooking and heating. Rural households in developing countries, including Nigeria collect food, firewood, medicinal plants and construction materials directly from the forest. The factors that condition a household's economic reliance of forest resources vary depending on the resource endowment of the household, the household's demographic and economic characteristics and other factors such as markets, prices and technologies (Babulo et al., 2008). Forest resources represent a common heritage and tend to be shared by a great majority of people (Nkem et al., 2007). People have realized a business in firewood selling. When driving along the major roads of the country especially those of the rural areas, one is welcomed by piles of fuelwood on the roadside. As a result of the high rate of unemployment in the country, many people are joining the fuelwood business as a source of income. These leads to an increase in the demand for fuelwood from the forest and people end up cutting standing trees that are not dry and deforestation is encouraged.

\section{RESEARCH METHODOLOGY}

Study Area. The study was carried out in Oyo state which is one of the major states in southwestern Nigeria and because active felling of trees, wholesale and retail selling of fuel wood takes place there. Multi stage, purposive and random sampling producers were used for the study. Stage one was the purposive selection of Oyo state due to its presence of active fuel wood markets. Stage two was the selection of local government areas with high fuel wood marketers which are Ibadan North Local Government, Ibadan North East Local Government, Akinyele Local Government, Ibadan south Local Government and Egbeda Local Government. The third stage was the random sampling of ten (10) fuel wood marketers from each of the local governments. Primary data was used for the study and the data was obtained using structured questionnaires administered to a total of 50 respondents in the selected five local government areas. Data were collected on the marketers' gross income, cost of acquisition, transportation, storage and so on.

Analytical Techniques. Data collected were analyzed using budgeting technique and gross marging margin analysis:

$$
\text { Gross margin }(G . M)=G I-T V C
$$

where: G M = Gross margin; G I = Gross Income; T V C = Total Variable Cost.

\section{RESULTS OF RESEARCH}

The results in table 1 revealed that none of the respondents were less than 30 years old and $12 \%$ were between 31 and 40 years while $44 \%$ were between 41 and 50 years. Moreover, $44 \%$ were greater than 50 years old. 
This revealed that fuel wood market in the study area is a business for the adults both in their mid and late years. It therefore serves as a business which the aged can fall back on when they are no more capable of jumping up and down for survival. At the same time, it accommodates adults in their mid-years that are still active and able to go to the forest and bushes in felling and collecting the wood; and also in bringing the wood out to cities, towns and villages. These groups of adults are usually found at the producer/ feller levels while the aged occupies the retailers' level.

It was observed that none of the fuel wood marketer used for the study was less than 30 years because most young ones are not yet aware of the profitability of the business but consider white collar job as the ultimate. This support Afolabi (2009) stated that this age distribution can have positive as well as negative impacts on the business aggressiveness of the marketers. It was also observed from the study that $86 \%$ of fuel wood marketers were females while only $14 \%$ were male. This therefore shows that fuel wood market is a business for both male and females. Though the business is a rigorous business which is supposed to be dominated by the male gender but recent development in the business has made a clear way for the female gender to make wave in the business. It was found from the study that the male gender handled the rigorous part; as they are the ones that go to the forest, identify the trees that are ready for harvest, fell them, cut them into desired sizes, packed, tight and load them into the vehicles while the females transported them to the markets for sales and distribution.

The study also revealed that majority of the marketers (48\%) were widows, $30 \%$ were married, $20 \%$ were divorced and only $2 \%$ were singles. This therefore suggests that marketing fuel wood plays a vital role in family sustainability especially at grassroots' level. As observed from the study, $68 \%$ of single parent depends on the business as their major source of livelihood. Having only $2 \%$ of the singles that engaged in the business revealed that there is dearth of awareness on the prospects of marketing fuel wood among the single folks who contributes largest percentage of the unemployed in Nigeria

This support (Ndaghu et al., 2011) who reported that non timber forest tree resources (NTFTR) have important contribution to the wellbeing of the rural poor. They further declared that NTFTRs such as fuel wood, locust beans etc provides food, sources of income and raw material for cottage industries that have supplied life sustaining strategies in the communities. It also confirmed Latiff et al. (2002) who reported that $80 \%$ of the people living in extreme poverty depend on forest resources such as fuel woods as their source of livelihood.

The study also showed that $38 \%$ of fuel wood marketers had no formal education, $44 \%$ had primary education, $16 \%$ had secondary education and just $2 \%$ had tertiary education. This suggests that education level of the marketers is extremely low and might have adverse effects on the efficiency, profitability as well as adoption of innovations by the marketers. This agree with Oluwasola (2010) who declared in his study that low level of education among respondents can have serious implications on their ability to access information, use new technological innovations and even access or procure credits from formal financial information. The study revealed that $98 \%$ of the markers were Yoruba which may be due to the fact that Yoruba tribe dominates the study areas. This supports Sekunmade and Oluwatayo (2011) who claimed that the location of most forest resources has great influence on the group of people that engage in its business.

$28 \%$ of the marketers were found to have between 1 to 5 years of business experience. $22 \%$ had between 6 to 10 years, $36 \%$ had 11 to 20 years while $14 \%$ had more than 20 years of business experience. This finding shows that marketing/ business experience is an important factor to consider in the business. It is thus not a business that anybody can just venture into without adequate experience of the business. This supports the statement of Adeoye et al., (2011) which states that the higher the numbers of years a marketer engage in a particular business, the better he become in the business.

The result showed that $16 \%$ of the marketers were producers/fellers. $32 \%$ were wholesalers, $46 \%$ were retailers and $6 \%$ serves as both wholesalers and retailers concurrently. This hence indicates that retailers dominate fuel wood market though the wholesalers have better opportunities to make higher returns from their market. This finding supports Afolabi (2009) which stated that retailers usually dominate marketing of agricultural products which may be due to the small capital investment required to start the business at retail level. 
Table 2 - Socio-economic characteristics of respondents

\begin{tabular}{|c|c|c|c|}
\hline Age in years & Frequency & Percentage cumulative & Percentage \\
\hline$<20$ & 0 & 0 & 0 \\
\hline $20-30$ & 0 & 0 & 0 \\
\hline $31-40$ & 6 & 12 & 12 \\
\hline $41-50$ & 22 & 44 & 56 \\
\hline$<50$ & 22 & 44 & 100 \\
\hline Total & 50 & 100 & \\
\hline \multicolumn{4}{|l|}{ Gender } \\
\hline Male & 7 & 14 & 14 \\
\hline Female & 43 & 86 & 100 \\
\hline Total & 50 & 100 & \\
\hline \multicolumn{4}{|l|}{ Marital Status } \\
\hline Singles & 1 & 2 & 2 \\
\hline Married & 15 & 30 & 32 \\
\hline Divorced & 10 & 20 & 52 \\
\hline Widow/widower & 24 & 48 & 100 \\
\hline Total & 50 & 100 & \\
\hline \multicolumn{4}{|l|}{ Educational Status } \\
\hline No Formal Education & 19 & 38 & 38 \\
\hline Primary Education & 22 & 44 & 82 \\
\hline Secondary Education & 8 & 16 & 98 \\
\hline Tertiary & 1 & 2 & 100 \\
\hline Total & 50 & 100 & \\
\hline \multicolumn{4}{|l|}{ Tribe } \\
\hline Yoruba & 48 & 96 & 96 \\
\hline Hausa & 0 & 0 & 96 \\
\hline Ibo & 2 & 4 & 100 \\
\hline Total & 50 & 100 & \\
\hline \multicolumn{4}{|c|}{ Marketing Experience in years } \\
\hline $1-5$ & 14 & 28 & 28 \\
\hline $6-10$ & 11 & 22 & 50 \\
\hline $11-20$ & 18 & 36 & 86 \\
\hline$>20$ & 7 & 14 & 100 \\
\hline Total & 50 & 100 & \\
\hline \multicolumn{4}{|l|}{ Tvpes of sellers } \\
\hline Wood feller/ Producers & 8 & 16 & 16 \\
\hline Wholesalers & 16 & 32 & 48 \\
\hline Retailers & 23 & 46 & 94 \\
\hline Wholesaler/Retailers & 3 & 6 & 100 \\
\hline Total & 50 & 100 & \\
\hline
\end{tabular}

Source: Field survey, 2012.

Profitability. The results in table 2 showed that the total revenue per month is $\# 1$, 914,500 while each marketer earns $\$ 38,290.00$ in a month. The marketing cost incurred was \#1,586,591.00 per month while each marketer incurs $\$ 31,731.82$ per month. The gross margin of marketing fuel wood is therefore $\$ 327,909.00$ per month while each marketers smiles home with $\approx 6,558.18$. The Benefit- Cost ratio was 1.21. Benefit -Cost ratio therefore indicated that for every $\$ 100$ invested in the business, there is a return of $\$ 21.00$. This shows that the business is a profitable venture. This agrees with Larinde and Olasupo, (2011) which stated that fuel wood trade is very profitable as average fuel wood marketer is able to recoup his or her investment with better returns in short period of time.

It was also discovered from the study that transportation is the number one constraint in marketing fuel wood. The result in table 3 showed that $30 \%$ of the marketers complained that there is poor road network linking major sources of fuel wood zones to the markets and as a result, marketers find it difficult to convey their goods to the markets. Similarly, there were no stand- by vehicles navigating the fuel wood source-zones and the few available ones were expensive to use. This hence leads to increase in marketing cost and majority of them could not afford it.

This supports Latiff et al. (2002) who declared transportation as a major challenge to agriculture in Nigeria. The result also revealed that season of the year is another constraint to profitability of marketing fuel wood. 28 percent of the marketers agreed that fuel wood market is highly seasonal. It was discovered that fuel wood commands high price in wet 
season compared to dry season because fuel wood is not always available in wet season due to the in-accessibility of most forests and park lands in wet season. Most vehicles do break down on the way. More-over, the fuel woods from the forest in wet season are always wet and unsuitable for immediate use. The marketers that have sheds or store house(s) to keep the fuel wood that are obtained in dry season are usually the 'king' as they monopolize the market in wet season.

Table 2 - Profitability Analysis of Fuel wood

\begin{tabular}{l|l} 
& Amount (\$) \\
Total Revenue (TR) & $1,914,500.00$ \\
Average Total Revenue (ATR) per month & $38,290.00$ \\
Total Variable Cost (TVC) & $1,586,591.00$ \\
Average Variable Cost (AVC) & $31,731.82$ \\
Gross Margin (GM) & 327,909 \\
Average Gross Margin & $6,558.18$ \\
Benefit Cost Ratio (TR/ TVC) & 1.21 \\
\hline
\end{tabular}

Source: Field Survey, 2012.

Table 3 - Constraints in fuel wood marketing

\begin{tabular}{|l|c|c|c|}
\hline \multicolumn{1}{|c|}{ Constraints } & Number of respondents & Percentage of respondents & Cumulative Percentage \\
\hline Transportation & 15 & 30 & 30 \\
\hline Season & 14 & 28 & 58 \\
\hline Government Policy & 12 & 24 & 82 \\
\hline Capital set up & 8 & 16 & 98 \\
\hline Market fluctuation & 1 & 2 & 100 \\
\hline \multicolumn{1}{|c|}{ Total } & 50 & 100 & \\
\hline
\end{tabular}

Source: Field survey, 2012.

Instability in government policy as well as government insincerity in implementing the policy is another major constraint to fuel wood markets. It was discovered from the result that instability in government policy as well as government insincerity in implementing the policies prevents the marketers from accurately predicting and effectively preparing for the business activities. Government incessant closing down of forests, park lands and games reserves also prevents the marketers from obtaining the best from the business. Furthermore, most forest guards will not perform their duty effectively unless the marketers give them extra money. It was also found that the capital set up for the business was enormous for average Nigerian based on the recent economic situation of the country while market fluctuation was the least constraint to marketing fuel wood.

\section{CONCLUSION AND RECOMMENDATIONS}

The study revealed that $56 \%$ of the marketers belong to the active segment of the population while the remaining $44 \%$ belong to the aged group. Analysis also showed that $86 \%$ of the marketers were females while the remaining $14 \%$ of them were males. Results showed that $38 \%$ of the marketers has no formal education, $44 \%$ had just primary education, $16 \%$ secondary education while $2 \%$ has tertiary education. Most of the marketers $(96 \%)$ in the study area are Yoruba. Few lbo (4\%) involve in fuel wood trade while there is no Hausa $(0 \%)$ in the market in Oyo state. The study also revealed that marketing experience is very important in the fuel wood trade as $50 \%$ of the marketers claimed to has between 11 to more than 20 years marketing experience, $22 \%$ has $6-10$ years experience and $28 \%$ has $1-5$ years experience. This also revealed that people are gaining entry into the market on a regular basis. The study also revealed that fuel wood market is dominated by retailer which accounted for $46 \%$ of the sellers such as wood fellers/ producers $(16 \%)$, wholesalers $(32 \%)$, wholesalers/retailers $(6 \%)$ of the marketers. The profitability analysis showed that an average marketer incurred an average variable cost of $\$ 31,731.82$ per month but earned average revenue of $\$ 38,290.00$ per month which indicates that an average marketers earned \#327,909 as gross margin per month. The study revealed that the Benefit-Cost Ratio was 
1.21. Transportation, season and government policy are the major marketing constraints of fuel wood. It is therefore recommended that government should provide good transportation incentives such as good road networks, sound vehicles, and so on that will make the business easy for fuel wood marketers. Moreover, government needs to review the forest policy based on the condition of the present market conditions so that much people can benefit from the income generating opportunities that fuel wood offers.

\section{REFERENCES}

1. Adeoye I.B., Olajide-Taiwo, F.B, Adebisi-Adelani O., Usman J. M, Badmus M.A (2011). Economic Analysis of Watermelon Based Production System in Oyo State, Nigeria. ARPN Journal of Agricultural and Biological Science, 6(7).

2. Afolabi J.A. (2009). An Assessment of Gari Marketing in South-Western Nigeria. Journal of Social Science, 21(1): 33-38.

3. Afolabi J.A., 2004, Evaluation of Beef Marketing in Osun State, Nigeria. Journal of Agriculture, Forestry and Fisheries, 5(2): 29-32.

4. Awah S.B. (1995). The rural woman and the importance of fuel wood in household energy consumption in the Diamare division of the Far North Province. Student end of course memoir. National Institute of Rural Development. Dschang, University Center.

5. Browning, E. K and J.M. Browning, 1992. Microeconomic Theory and Applications, Fourth Edition, Harper Collins Publishers Inc., p: 718.

6. CIFOR, 2009. Center for International Forest Research: Science for Forest and People.

7. Cleaver K.M., 1985. The Impact of price and Exchange Rate Policies on Agriculture in Sub- Saharan Africa, World Bank Staf Working Paper, 728.

8. F.A.O. (1990): The fuel wood crisis and population Africa. Parts 1-4.

9. F.A.O. (2004): Assessing Forestry Project Impact: Issues and Strategies, F.A.O., Rome 4-6 pp., http://www.cifor.cgiar.org/Publications/Corporate/FactSheet/livelihood.htm

10. Horgan G.P. (2001): Wood energy economics.

11. Kalu C; Atagana, S and Ani, P.I. (2009): Marketing of Round Logs in Benin City, Edo State, Nigeria. Journal of Applied Science Research, 5(7): 785-789.

12. Larinde S.L. and O.O Olasupo, (2011): Socio-economic importance of fuel wood production in Gambari Forest Reserve Area, Oyo State. Journal of Agriculture and Social Research 11(1), 2011.

13. Latiff, A, Shinwari, Z. K, Begum, S. (2002). Potentials and Market Status of Mushrooms and Non-timber Forest Product in Pakistan. Ethno-Botany Project, WWF-P, Peshawar, Pakistan.

14. Ndaghu A.A, Taru V.B, Tizhe, I, Tizhe, J (2011). Analysis of Socio-Economic Characteristics of Fuel Wood Marketers in Yola Metropolis, Adamawa State, Nigeria. Journal of Human Ecology, 36(2): 153-157.

15. Nkem, J., H. Santos, D. Murdiyarso, M. Brockhaus and M. Kanninem, 2007. Using tropical forest ecosystem goods and services for planning climate change adaptation with implications for food security and poverty reduction. SAT e J 4: 1-23.

16. Oluwemimo Oluwasola (2010): Stimulating rural employment and income for cassava (Manihot sp.) processing farming households in Oyo State, Nigeria through policy initiatives. Journal of Development and Agricultural Economics 2(2), pp. 018-025.

17. Orosanye, L. U. I. (2003): Protection of the environment: An overview, International Journal of Environmental Issues, 2(1): 23-25.

18. Sekunmade, A.B and Oluwatayo, I.B (2011). Economic Analysis of Plank Production in Gbonyin Local Government Area of Ekiti State, Nigeria. International Journal of Agricultural Economics \& Rural Development 4(1). 